\section{Allele dosage of PVY resistance genes in potato clones using molecular markers}

\author{
Raquel Bartz Kneib ${ }^{1}$, Roberta Bartz Kneib ${ }^{2}$, Arione da Silva \\ Pereira $^{3}$ and Caroline Marques Castro ${ }^{3^{*}}$
}

\begin{abstract}
Potato virus Y (PVY) is considered one of the most important pathogens in potato crop. The objective of this study was to estimate the allele dosage of Ry genes and select clones with multiple copies of resistance alleles to be used as parents in potato breeding programs. Seven clonal families were genotyped, including five parents with resistance to PVY. For the allele $R y_{\text {adg }}$ based on the marker RYSC3, four parents are simplex, and one is duplex. For the allele Ry sto based on the marker M45, two parents are simplex and one is duplex. For two parents, the observed frequencies of the allele $R y_{\text {sto }}$ did not statistically adjust to any of the proposed genotypic constitutions. Based on the results obtained, both markers must be used in marker assisted selection for resistance to PVY, in order to decrease the error of discarding clones with only one of the alleles.
\end{abstract}

Key words: Solanum tuberosum L., genetic improvement, Potato virus Y, RYSC3, M45.

\section{INTRODUCTION}

The cultivated potato, Solanum tuberosum L., is the third most produced food in the world, after rice and wheat, with annual yield superior to 370 million tons. In Brazil, potato is grown in the Midwest, Northeast, Southeast and South regions, with annual yield above 3.5 million tons in 2014 (http:// www.ibge.gov.br/home/).

Potato virus Y (PVY) causes losses in yield and in quality of tubers, due to the presence of necrotic spots, and it is considered the most important virus in potato cultivation. The damage caused by PVY surpasses that caused by the potato leafroll virus (PLRV), which used to be considered the main virus in potato crops (Beczner et al. 1984, Nolte et al. 2004, Ávila et al. 2009).

Vegetative propagation, which is commercially used by potato producers, is the main form of disseminating the virus from one generation to another, via infected tubers. Thus, constant seed renewal is necessary to avoid the occurrence of PVY (Ávila et al. 2009). The purchase of seed tubers represents the highest cost in the potato production system, which could be reduced by using resistant cultivars, enabling the producer to use tubers harvested from their own cultivation for two or more crops, after installing a field with virus free seed tubers (Brune and Melo 2002).

Some wild potatoes species have been identified as resistant to viruses and used in breeding programs for over 80 years. This resistance is controlled by major genes with dominance effect, the Ry genes, which confer extreme
Crop Breeding and Applied Biotechnology 17: 306-312, 2017 Brazilian Society of Plant Breeding. Printed in Brazil http://dx.doi.org/10.1590/198470332017v17n4a47

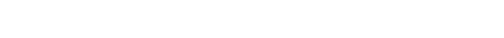


resistance to PVY (Ribeiro et al. 2014). These genes were identified in Solanum tuberusum ssp. andigena $\left(R y_{a d g}\right)$, on chromosome XI; in S. stoloniferum $\left(R y_{\text {sto }}\right)$, on chromosome XI; and in S. chacoense $\left(R y_{\text {chc }}\right.$ ), on chromosome IX (Cockerham 1970, Valkonen et al. 1994, Tiwari et al. 2012).

The use of molecular markers is an important tool to increase the efficiency of the selection of genotypes of interest, and consequently to reduce the time required for the development of new cultivars (Koeyer et al. 2010). The mapping of genes of interest in wild species has allowed the development of molecular markers SCAR (Sequence Characterized Amplified Region), which amplify the region containing the allele of interest by the annealing of specific primers adjacent to this region (Paran and Michelmore 1993).

Hämäläinem et al. (1998) cloned and sequenced the region in potato genome linked to the allele $R y_{a d g}$, and Kasai et al. (2000) developed the marker SCAR, denominated RYSC3, which amplifies this region. Likewise, Brigneti et al. (1997) developed the marker SCAR, which amplifies the region linked to the $R y_{\text {sto }}$ allele, denominated M45.

The cultivated potato, in general, is a tetraploid species. The Ry gene confers extreme resistance or immunity in simplex form (Ryryryry). Therefore, considering chromosome segregation in a cross between simplex parent and susceptible parent, a ratio of 1 resistant: 1 susceptible is expected in the progeny. However, if duplex (RyRyryry) or triplex parents (RyRyRyry) are used, the ratio increases to 5 resistant: 1 susceptible and 1 resistant: 0 susceptible progeny, respectively, which consequently increases the probability of obtaining clones resistant to PVY associated with other traits of interest (Solomon-Blackburn and Barker 2001). Thus, for more efficient use of the Ry gene in potato breeding, the knowledge on the allelic dosage of this gene in the parents available in the breeding program is crucial (Koeyer et al. 2010). One way of estimating the allelic dosage of a gene in a particular genotype is by the analysis of the segregation of this gene in the progeny, obtained by test crosses, i.e., with a nuliplex parent (susceptible) (Ribeiro et al. 2006, Heldák et al. 2007, Ortega and Lopez-Vizcon 2012, John et al. 2013).

The objectives of this study were to evaluate the efficiency of the use of RYSC3 and M45 markers in assisted selection for resistance to PVY, and estimate the allelic dosage of Ry genes in parents of the potato breeding program of Embrapa.

\section{MATERIAL AND METHODS}

The study was carried out at the Molecular Biology Laboratory of Embrapa Temperate Agriculture, in Pelotas, RS. Progenies of seven clonal families were evaluated, including five parents resistant to PVY (Table 1).

Parents were obtained from botanical seeds of the International Potato Center (CIP), and presented in their genealogy clones such as LT-7, LT-8 and XY14, resistant to Y virus (Andrade et al. 2009, Ribeiro et al. 2014), which explains the presence of resistance genes in the genotypes used. The genotypes C1883-22-97, C2372-02-02, C2388-01-02 and C238901-02 were selected for having good adaptation to the conditions of production in southern Brazil, as well as for their desirable agronomic characteristics. These genotypes are advanced lines of the potato breeding program of Embrapa Temperate Agriculture. The genotype MB9846-1 was selected for resistance to potato bacterial wilt, caused by Ralstonia solanacearum associated with satisfactory tubers appearance and good yield.

Sexual seeds obtained from the crosses of parents were treated with gibberellic acid solution at 1500 ppm for 24 hours in order to break dormancy, and were sown in August 2012. About 30 days after sowing, approximately 120 seedlings of each family were transplanted to plastic bags containing $250 \mathrm{~mL}$ organo-mineral substrate, and remained in greenhouse during the vegetative growth cycle.

Collection of young leaves of each clone for DNA extraction started about one month after transplanting, and extraction was carried out according to the protocol described by DarT ${ }^{\circledR}$ (http://www.diversityarrays.com/samplesub.html). The quality of the DNA extracted was verified in $1 \%$ agarose gel, and its concentration was quantified in a fluorometer.

After the adjustment of the DNA concentration, the microsatellite marker STI0003 was used, which is widely applied in the characterization of potato genotypes to confirm the quality of the DNA and prevent the occurrence of false negative results in PCR reactions, following the protocol described by Ghislain et al. (2009).

Progenies genotyping was carried out based on the marker SCAR RYSC3, developed by Kasai et al. (2000), which amplifies a $321 \mathrm{bp}$ band when the genotype presents the $R y_{\text {adg }}$ allele; and based on the marker M45, developed by 
Brigneti et al. (1997), which amplifies a 500bp band when the genotype presents the $R y_{\text {sto }}$ allele. For both markers, PCR reactions were carried out in a final volume of $9.0 \mu \mathrm{L}$, containing $20 \mathrm{ng}$ genomic $\mathrm{DNA}, 0.25 \mu \mathrm{M}$ of each primer, $0.125 \mathrm{mM}$ dNTPs, $2 \mathrm{mM} \mathrm{MgCl}_{2}$, and $1 \mathrm{U}$ TaqDNA polymerase.

The amplification program was performed according to the following conditions for the RYSC3 marker: initial denaturation cycle at $93^{\circ} \mathrm{C}$ for $9 \mathrm{~min}$, followed by 30 cycles at $94^{\circ} \mathrm{C}$ for $45 \mathrm{~s}$; 55 으 for $45 \mathrm{~s}$ for primer annealing; extension at $72{ }^{\circ} \mathrm{C}$ for $1 \mathrm{~min}$; and final extension at $72{ }^{\circ} \mathrm{C}$ for $5 \mathrm{~min}$. For the M45 marker, PCR conditions were: $94^{\circ} \mathrm{C}$ for $1 \mathrm{~min}$, followed by 30 cycles at 94 으 for $20 \mathrm{~s} ; 58^{\circ} \mathrm{C}$ for $20 \mathrm{~s}$; and 72 으 for 20s; with a final extension at $72{ }^{\circ} \mathrm{C}$ for $20 \mathrm{~min}$.

Amplification products were separated by electrophoresis in $1 \%$ agarose gel and visualized in photodocumentador. Images were stored in a computer for the evaluation of the amplification products. The molecular weight marker $1 \mathrm{~kb}$ Plus (Invitrogen) was used as a reference to estimate the size of the amplified fragments, using the computer software Bio - 1D, Version 12.14. The potato cultivars Chieftain and Iporá were used, respectively, as negative and positive control for both genes in PCR reactions, following the methodology proposed by Rizza et al. (2006).

Clones from each cross were evaluated for the presence or absence of the $321 \mathrm{bp}$ band for the resistance allele $R y_{a d g}$, and for the presence or absence of the $500 \mathrm{bp}$ band for the resistance allele $R y_{\text {sto, }}$, according to Kasai et al. (2000) and Brigneti et al. (1997), respectively. To estimate the allelic dosage of the parents, the double reduction frequency $\alpha=0.1566$ was considered to determine genotypic constitutions hypotheses (Mendoza et al. 1996), which were tested by the $\chi^{2}$ test, using the following formula: $\chi^{2}=\Sigma\left[(0-E)^{2} / E\right]$, where $O$ is the frequency observed for each class, resistant or susceptible, and $E$ is the expected frequency for each class.

The following hypotheses were tested in relation to the possible genotypic constitutions of parents in relation to the allelic dosage of the $R y$ genes, as described by Andrade et al. (2009): Nuliplex (ryryryry): $\mathrm{H}_{0}$ - the dominant allele of the Ry gene segregates in the ratio of 0 resistant: 1 susceptible; Simplex (Ryryryry): $\mathrm{H}_{0}$ - the dominant allele of the Ry gene segregates in a ratio of 1 resistant: 1.17 susceptible; Duplex (RyRyryry): $\mathrm{H}_{0}$ - the dominant allele of the Ry gene segregates in the ratio of 3.56 resistant: 1 susceptible; Triplex (RyRyRyry): $\mathrm{H}_{0-}$ the dominant allele of the Ry gene segregates in the ratio of 24.5 resistant: 1 susceptible; and Quadruplex (RyRyRyRy): $\mathrm{H}_{0}$ - the dominant allele of the Ry gene segregates in the ratio of 1 resistant: 0 susceptible.

\section{RESULTS AND DISCUSSION}

In total, seven crosses were carried out, and 711 genotypes were obtained, ranging from 68 to 109 genotypes per family. Each genotype was analyzed for the presence or absence of the Ry gene, using the markers RYSC3 and M45 (Figure 1, Table 1).

Molecular markers identified 309 clones (43.46\%) with the $R y_{\text {adg }}$ allele, suggesting that they are resistant to PVY; and 279 clones (39.24\%) with the $R y_{\text {sto }}$ resistance allele. These results show that the use of molecular assisted selection with markers RYSC 3 and M45 can early eliminate more than $50 \%$ of the study population, which is composed of clones susceptible to PVY.

Several studies have been carried out to validate the RYSC3 marker by research groups in Chile, Spain, United States and Brazil, showing the efficiency of this marker in the selection of clones resistant to PVY (Sagredo et al. 2009, Ottoman et al. 2009, Kasai et al. 2000, Lopez-Pardo et al. 2013, Andrade et al. 2009, Ribeiro et al. 2006, Neder et al. 2010).

Sagredo et al. (2009) obtained almost $100 \%$ efficacy by
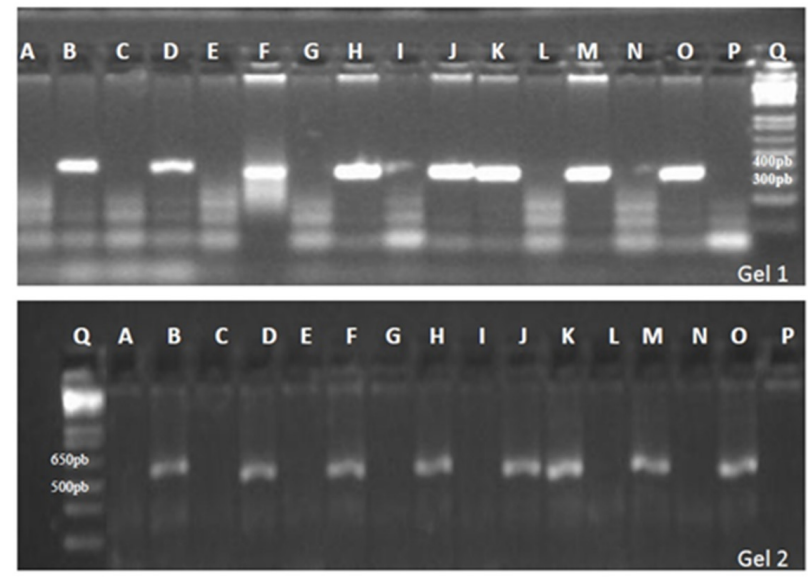

Figure 1. Molecular profile of parents and controls for the markers RYSC3 (Gel 1) and M45 (Gel 2), in 1\% agarose gel. Identification: A) Chieftain; B) Iporá; C) BRS Clara; D) C1883-22-97; E) BRS Ana; F) C1883-22-97; G) BRS Ana: H) C2372-02-02; I) Caesar; J) C237202-02; K) C2388-01-02; L) Asterix; M) C2389-01-02; N) Asterix; O) MB 9846-1; P) 5897-1; Q) 1Kb Plus DNA Ladder (Invitrogen). 
using the RYSC3 marker to evaluate progenies of three clonal families, while in bioassays, efficacy was lower than $90 \%$, mainly due to problems such as the inefficiency in the inoculation, resulting in false negatives.

Mechanical inoculation of plants with PVY, followed by the detection of the presence of the virus by the ELISA test is an alternative used to validate SCAR markers (Whitworth et al. 2009). When comparing the ELISA test with the marker RYSC3, studies demonstrate high coincidence, greater than 95\%, between the positive results for resistance to PVY (Ottoman et al. 2009). These results evidence the importance of the discovery, validation and use of molecular markers as a tool to make breeding programs more efficient.

Among the families evaluated, C-6 (C2389-01-02 x Asterix) stood out with the highest number of clones with the PVY resistance gene; $74 \%$ of the clones had the $R y_{\text {adg }}$ allele; and $71 \%$ presented the $R y_{\text {sto }}$ allele (Table 1 ).

In the potato breeding program, more than 40 traits are involved in the selection process (Gebhardt et al. 2007). In the C-6 family, given the high percentage of clones carrying the PVY resistance genes, the probability of finding a clone with PVY resistance associated with commercial characteristics of interest is higher than in other families.

Due to the great number of agronomic traits that need to be addressed in the development of a new potato cultivar, together with the autotetraploid nature of the species, the use of allele dosage of a given gene associated with a trait of interest is of great importance to guide crosses, aiming at the maximization of the efficiency in the transmission of this trait.

Analysis of segregation of the $R y_{\text {adg }}$ and $R y_{\text {sto }}$ alleles was used to estimate the allele dosage in parents resistant to PVY evaluated in this study. Tables 2 and 3 show the results of the $\chi 2$ test for each hypothesis of genotype constitution tested for $R y_{\text {adg }}$ and $R y_{\text {sto }}$ alleles, respectively.

For the $R y_{a d q}$ allele, based on the RYSC3 marker, of the five parents resistant to PVY, four [C1883-22-97 (C-1 and C-2 families), C2372-02-02 (C-3 and C-4 families), C2388-01-02 (C-5 family), and MB9846-1(C-7 families)] are simplex, with

Table 1. Total number of genotypes analyzed per family, number of genotypes with the presence (+) or absence (-) of the $321 \mathrm{pb}$ band, for the marker SCAR RYSC3, and presence (+) or absence (-) of the 500bp band, for the marker SCAR M45, and percentage of clones with the presence of the alleles $R y_{a d g}$ and $R y_{\text {sto }}$ per family

\begin{tabular}{|c|c|c|c|c|c|c|c|c|}
\hline Family & Male $x$ female parent & Total & \multicolumn{2}{|c|}{ RYSC3 } & $\begin{array}{l}\text { Clones with the pres- } \\
\text { ence of the gene } R y_{a d g} \\
(\%)\end{array}$ & \multicolumn{2}{|c|}{ M45 } & $\begin{array}{c}\text { Clones with the } \\
\text { presence of the gene } \\
R y_{\text {sto }}(\%)\end{array}$ \\
\hline C-1 & BRS Clara x C1883-22-97* & 105 & 36 & 69 & 34 & 29 & 76 & 28 \\
\hline $\mathrm{C}-3$ & BRS Ana x C2372-02-02* & 114 & 39 & 75 & 34 & 27 & 87 & 24 \\
\hline C-4 & Caesar x C2372-02-02* & 104 & 40 & 64 & 38 & 34 & 70 & 33 \\
\hline $\mathrm{C}-7$ & MB9846-1* x 5897-1 & 109 & 47 & 62 & 43 & 49 & 60 & 45 \\
\hline Total & & 711 & 309 & 402 & 49 & 279 & 432 & 39 \\
\hline
\end{tabular}

* Parent resistant to PVY, carrying the $R y_{\text {adg }}$ and $R y_{\text {sto }}$ genes.

Table 2. Significance values of the $\chi 2$ test for the genetic constitutions nuliplex (ryryryry), simplex (Ryryryry), duplex (RyRyryry), triplex (RyRyRyry), and quadruplex (RyRyRyRy) in the evaluation of seven potato clonal families for the $R y_{a d g}$ allele

\begin{tabular}{|c|c|c|c|c|c|}
\hline \multirow{2}{*}{ Families } & \multicolumn{5}{|c|}{ Genetic contitution } \\
\hline & Nuliplex & Simplex & Duplex & Triplex & Quadruplex \\
\hline C-1 & $129552.69 * *$ & 5.88 & $117.57^{* *}$ & $1064.09 * *$ & $476052.69 * *$ \\
\hline $\mathrm{C}-2$ & $144350.02 * *$ & 6.27 & $124.58^{* *}$ & $1246.58 * *$ & $532850.02 * *$ \\
\hline$C-3$ & $152048.69 * *$ & 6.47 & $128.09 * *$ & $1158.11 * *$ & $56244.69 * *$ \\
\hline$C-4$ & $159950.77^{* *}$ & 2.43 & $95.30 * *$ & $916.32^{* *}$ & $409550.77^{* *}$ \\
\hline$C-5$ & $122466.03 * *$ & 0.79 & $28.10 * *$ & $359.13 * *$ & $108866.03^{* *}$ \\
\hline
\end{tabular}

** significant at $1 \%$ probability 
Table 3. Significance values of the $\chi 2$ test for the genetic constitutions nuliplex (ryryryry), simplex (Ryryryry), duplex (RyRyryry), triplex (RyRyRyry), and quadruplex (RyRyRyRy) in the evaluation of seven potato clonal families for the allele $R y_{\text {sto }}$

\begin{tabular}{lccccc}
\hline \multirow{2}{*}{ Families } & \multicolumn{3}{c}{ Genetic Constitution } \\
\cline { 2 - 6 } & Nuliplex & Simplex & Duplex & Triplex & Quadruplex \\
\hline C-1 & $84058.02^{* *}$ & $14.41^{* *}$ & $156.1^{* *}$ & $1306.08^{* *}$ & $577558.02^{* *}$ \\
C-2 & $129551.36^{* *}$ & $8.32^{* *}$ & $135.04^{* *}$ & $1320.03^{* *}$ & $562451.35^{* *}$ \\
C-3 & $72858.80^{* *}$ & $23.02^{* *}$ & $196.95^{* *}$ & $1585.72^{* *}$ & $756858.79^{* *}$ \\
C-4 & $115554.24^{* *}$ & $7.51^{* *}$ & $125.08^{* *}$ & $1109.01^{* *}$ & $489954.23^{* *}$ \\
C-5 & $108866.03^{* *}$ & 0.16 & $34.66^{* *}$ & $408.04^{* *}$ & $122466.03^{* *}$ \\
C-6 & $504058.82^{* *}$ & $24.99^{* *}$ & 2.92 & $166.92^{* *}$ & $84058.83^{* *}$ \\
C-7 & $240046.06^{* *}$ & 0.06 & $69.82^{* *}$ & $838.61^{* *}$ & $359946.06^{* *}$ \\
\hline
\end{tabular}

** See Table 2

a unique copy of the $R y_{\text {adg, }}$, allele, while the parent C2389-01-02 (C-6 family) is duplex (Table 2).

Similarly to the results obtained by Andrade et al. (2009), in which the marker RYSC3 allowed selecting clones with multiple dosages of the $R y_{\text {adg }}$ allele, in this study, the marker demonstrated to be efficient in identifying genotypes resistant to PVY, and allowed the estimation of the allele dosage in the parents.

For the allele $R y_{\text {sto }}$, based on the marker M45, of the five parents resistant to PVY, two C2388-01-02 (C-5 family) and MB9846-1(C-7 family) are simplex, with a copy of the $R y_{\text {sto }}$ allele, while the parent C2389-01-02 (C-6 family) is duplex (Table 3), in agreement with the results obtained for the allele $R y_{\text {adg }}$ based on the RYSC3 marker. Conversely, for the parents C1883-22-97 (C-1 and C-2 families) and C2372-02-02 (C-3 and C-4 families), although the progenies descended from both parents amplify the fragment of $500 \mathrm{bp}$ (which confirms the presence of $R y_{\text {sto }}$ allele), the observed frequencies of presence of the allele $R y_{\text {sto }}$ in the four progenies evaluated, with values between $24 \%$ and $33 \%$ (Table 1), were not statistically adjusted to any of the proposed genotypic constitutions. A hypothesis to this fact is that the region adjacent to the allele $R y_{\text {sto }}$, in which annealing of primers specific of the M45 marker occurs, is more susceptible to the occurrence of mutations. Another hypothesis is the fact that this region is more distant from the target gene, allowing recombination, and consequently resulting in the non-amplification of the expected fragment and in the occurrence of false negatives.

In the evaluated clones $75.37 \%$ amplified for both markers, RYSC3 and M45, which is similar to the results obtained by Rizza et al. (2006). An explanation for the coincidence of amplification is that both markers are linked to the same gene, Ry (Flis et al. 2005, Song et al. 2005).

Some studies have shown that genes $R y_{\text {adg }}$ and $R y_{\text {sto }}$ are located in the chromosome $\mathrm{XI}$, and due to this proximity, they segregate together (Rizza et al. 2006, Tiwari et al. 2012).

In the present study, clones that amplified for only one of the markers were also identified (54 for RYSC3; and 29 for M45), corroborating the results found by Rizza et al. (2006). These authors state that this fact occurs due to events of genetic recombination or mutations in the region adjacent to $R y_{\text {adg }}$ and, or $R y_{\text {sto }}$, consequently hindering the annealing of primers.

According to Ribeiro et al. (2014), the marker RYSC3 is the most efficient for the selection of PVY resistant clones, since the marker is within the coding region of the gene Ry. However, results found in this study suggest that both markers should be used in the assisted selection for resistance to PVY in a population with S. tuberosum spp. andigena and S. stoloniferu in its genealogy, in order to avoid the discard of genotypes with only one of the genes.

\section{CONCLUSIONS}

Both markers, RYSC3 and M45, should be used in marker assisted selection to PVY, since some clones have only one of the resistance alleles. Parents that carry the Ry genes have distinct allelic dosages, i.e., C1883-22-97, C2372-0202, C2388-01-02 and MB9846-1 are simplex; and C2389-01-02 is duplex for both genes. By using a duplex parent in crosses with a susceptible clone, $97 \%$ is the probability of the progeny to present the resistance gene. Consequently, the possibility of associating agronomic traits of interest with resistance to PVY is high. 


\title{
ACKNOWLEDGMENTS
}

\author{
CAPES-Embrapa (15/2014), FAPERGS, CNPq, Embrapa Temperate Agriculture and UFPel.
}

\section{REFERENCES}

Andrade CM, Pinto CABP, Ribeiro SRRP, Peixoto LS and Vilela XMS (2009) Potato clones with multiple copies of the $R y_{\text {adg }}$ allele conferring resistance to Potato virus Y. Crop Breeding and Applied Biotechnology 9: 286-292.

Ávila AC, Melo PE, Leite LR and Inoue-Nagata AK (2009) Ocorrência de vírus em batata em sete estados do Brasil. Horticultura Brasileira 27: 490-497.

Beczner L, Horvath J, Romhanyi I and Forster H (1984) Studies on the etiology of tuber necrotic ringspot disease in potato. Potato Research 27: 339-352.

Brigneti G, Garcia-Mas J and Baulcombe C (1997) Molecular mapping of the potato virus $Y$ resistance gene $R y_{\text {sto }}$ in potato. Theoretical and Applied Genetics 94: 198-203.

Brune S and Melo PE (2002) Produção comprometida. Cultivar: Hortaliças e Frutas 13: 6-8.

Cockerham G (1970) Genetical studies on resistance to potato viruses X and Y. Heredity 25: 309-348.

Flis B, Hennig J, Strzelczyk-Zyta D, Gebhardt C and Marczewski W (2005) The Ry-fsto gene from Solanum stoloniferum for extreme resistant to Potato virus $Y$ maps to potato chromosome XII and is diagnosed by PCR marker GP122 718 in PVY resistant potato cultivars. Molecular Breeding 15: 95-101.

Gebhardt C, Li L, Pajerowska-Mukthar K, Achenbach U, Sattarzadeh A, Bormann C, llarionova E and Ballvora A (2007) Candidate Gene Approach to Identify Genes Underlying Quantitative Traits and Develop Diagnostic Markers in Potato. Crop Science 47: 106-111.

Ghislain M, Núñez J, Herrara MDR, Pignataro J, Guzman F, Bonierbale M and Spooner DM (2009) Robust and highly informative microsatellitebased genetic identity kit for potato. Molecular Breeding 23: 377-388.

Hämäläinem JH, Sorri VA, Watanabe KN, Gebhardt C and Valkonen JPT (1998) Molecular examination of a chromosome region that controls resistance to potato $\mathrm{Y}$ and $\mathrm{A}$ potyviruses in potato. Theoretical and Applied Genetics 96: 1036-1043.

Heldák J, Bezo M, Štefúnová V and Galliová A (2007) Selection of DNA markers for detection of extreme resistance to potato virus $Y$ in tetraploid potato (Solanum tuberosum L.) F1 progenies. Czech Journal of Genetics and Plant Breeding 43: 125-134.

John O, Kiarie N, Solomon S, Charles L, Nyongesa M, Muthoni J, Otieno S, Mbiyu M and Oyoo J (2013) Potato virus Y (PVY) and potato virus $X(P V X)$ resistance breeding in Kenya: applicability of conventional approaches. Agriculture and Biology Journal of North America 4: 398-405.

Kasai K, Morikawa Y, Sorri V, Valkonen JPT, Gebhardt C and Watanabe KN
(2000) Development of SCAR markers to the PVY resistance gene $R y_{\text {adg }}$ based on a common feature of plant disease resistance genes. Genome 43: 1-8.

Koeyer D, Douglass K, Murphy A, Whitney S, Nolan L, Song Y and Jong WD (2010) Application of high-resolution DNA melting for genotyping and variant scanning of diploid and auto tetraploid potato. Molecular Breeding 25: 67-90.

Lopez-Pardo R, Baradalla L, Ritter E and Galarreta JIR (2013) Validation of molecular markers for pathogen resistance in potato. Plant Breeding 132: 246-251.

Mendoza HA, Mihovilovich EJ and Saguma F (1996) Identification of triplex (YYYy) potato virus Y (PVY) immune progenitors derived from Solanum tuberosum ssp. andigena. American Potato Journal 73: 13-19.

Neder DG, Pinto CABP, Melo DS, Lepre AL and Peixouto LS (2010) Seleção de clones de batata com resistência múltipla à pinta preta e aos vírus X e Y. Ciência Rural 40: 1702-1708.

Nolte P, Whitworth JL, Thomton MK and Mcintosh CS (2004) Effect of seedborne Potato virus $Y$ on performance of Russet Burbank, Russet Norkotah and Shepody potato. Plant Disease 88: 248-252.

Ortega F and Lopez-Vizcon C (2012) Application of molecular markerassisted selection (MAS) for disease resistance in a practical potato breeding programme. Potato Research 55: 1-13.

Ottoman RJ, Hane DC, Brown CR, Yilma S, James SR, Mosley AR, Crosslin JM and Vales MI (2009) Validation and implementation of markerassisted selection (MAS) for PVY resistance ( $R y_{\text {adg }}$ gene) in a tetraploid potato breeding program. American Journal of Potato Research 86: 304-314.

Paran I and Michelmore RW (1993) Development of reliable PCR-based markers linked to downy mildew resistance genes in lettuce. Theoretical and Applied Genetics 85: 985-993.

Ribeiro AM, Pinto CABP, Andrade CM and Santos JB (2006) SCAR marker for the selection of $R y$-duplex potato clones immune to potato virus Y. Crop Breeding and Applied Biotechnology 6: 1-8.

Ribeiro SRRP, Pinto CABP, Costa SBFG, Menezes M and Figueira AR (2014) Resistance of potato clones to necrotic recombinant strains of potato virus y (pvy). Ciência e Agrotecnologia 38: 343-351.

Rizza MD, Vilar FL, Torres DG and Maeso D (2006) Detection of PVY extreme resistance gene in potato germplasms from Uruguayan breeding program. American Journal of Potato Research 83: 297-304.

Sagredo B, Mathias M, Barrientos C, Acuña I, Kalazick J and Rojas JS (2009) Evaluation of a SCAR RYSC3 marker of the $R y_{\text {adg }}$ gene to select resistant genotypes to Potato virus Y (PVY) in the Inia potato breeding program. Chilean Journal of Agricultural Research 69: 305-315.

Solomon-Blackburn RM and Barker H (2001) A review of host major-gene 


\section{RB Kneib et al.}

resistance to potato viruses $\mathrm{X}, \mathrm{Y}, \mathrm{A}$ and $\mathrm{V}$ in potato: genes, genetics and mapped locations. Heredity 86: 8-16.

Song YS, Heptin GL, Schweizer G, Hartl L, Wenzel G and Schwarzfischer A (2005) Mapping of extreme resistance to PVY (Rysto) on chromosome XII using anther-culture-derived primary dihaploid potato lines. Theoretical and Applied Genetics 111: 879-887.

Tiwari JK, Gopal J and Singh JB (2012) Marker-Assisted Selection for virus resistance in potato: Options and challenges. Potato Journal 39: 101-117.
Valkonen JPT (1994) Natural genes and mechanisms for resistance to viruses in cultivated and wild potato species (Solanum spp.). Plant Breeding 112: 1-16.

Whitworth JL, Novy RG, Hall DG, Crossilin JM and Brown CR (2009) Characterization of broad spectrum Potato Virus $\mathrm{Y}$ resistance in a Solanum tuberosum ssp. andigena derived population and select breeding clones using molecular markers, grafting, and field inoculations. American Journal of Potato Research 86: 286-296. 